\title{
The G20 Hub of Decentralizing Global Governance Authority ${ }^{1}$
}

\author{
J. Luckhurst
}

Jonathan Luckhurst - PhD, Associate Professor of International Relations at the Graduate School of International Peace Studies, Soka University; 1-236, Tangi-machi, Hachioji, 192-8577, Tokyo, Japan; E-mail: luckhurst@soka.ac.jp

\begin{abstract}
This article examines how the Group of Twenty (G20) became a hub of decentralizing authority in global economic governance since the 2008-09 global financial crisis. It analyzes how this forum responded to the crisis by decentralizing authority away from the Group of Seven/Eight (G7/8) and integrating more diverse actors and networks in global governance. The G20 also became an important hub for diffusing new policy norms and practices. These global crisis effects are linked to international authority shifts since the Cold War. The analytical approach combines, especially, social constructivist tools from the field of International Relations and insights from the sociology of professions literature. This involves analysis of strategic, political, and cognitive dimensions of authority, and a focus on the influence of global governance networks in G20 policy processes and practices. The research includes participant observation, semi-structured interviews and personal discussions with members of such G20 governance networks. The article indicates how the G20's role as a driver and conduit for shifts in global authority was augmented by the global financial crisis.
\end{abstract}

Key words: G20; hub; global governance; authority

For citation: Luckhurst J. (2019) The G20 Hub of Decentralizing Global Governance Authority. International Organisations Research Journal, vol. 14, no 2, pp. 7-30 (in Russian and English). DOI: 10.17323/1996-78452019-02-01.

This article examines how the Group of Twenty (G20) became a hub of decentralizing authority in global economic governance. Once upgraded to a leader-level meeting during the 2008-09 global financial crisis (GFC), the G20 became a key forum for decentralizing authority, extending it beyond the Group of Seven/Eight (G7/8) to the broader G20 membership and other actors. This complemented the G20's role as a hub in diffusing new global governance norms and policy practices.

The first section of the article defines the analytical framework, including analytical tools from the sociology of professions and "IR" social constructivism, and particularly the conceptual usage of "hub," "governance networks" and "authority." The second section examines how processes of decentralizing authority in international economic affairs, already evident since the late 20th century, increased after the Asian financial crisis and during the GFC. The third examines how the G20 became a global governance hub, during and subsequent to the GFC. The final section analyzes the significance of the G20 as a hub of decentralizing authority in global economic governance, especially its capacity to integrate and increase the influence of diverse networks of policy actors.

${ }^{1}$ The editorial board received the article in February 2019. 
The G20's role as a driver and conduit for shifts in global authority was substantially augmented by its redesign during the GFC, but persisted beyond it. This is crucial for understanding the importance of the leader-level forum. The present study analyzes how the $\mathrm{G} 20$ became authoritative in global economic governance, and its broader significance for world affairs, by assessing strategic, political and cognitive dimensions of its authority. This forum is likely to have lasting consequences, especially due to its global authority effects, despite what sceptics perceive as its diminishing cooperation in recent years.

\section{Analytical Framework}

The article focuses on a key facet of the G20's influence as a hub of global economic governance, that is, its role in decentralizing authority in this context. This has been an important aspect of the leader-level forum's diffusion of new global governance norms and practices since the GFC, especially due to strategic, political and cognitive authority effects of the global crisis.

There are a few conceptual dimensions to this study. The first is the notion of the G20 as a $h u b$ of global economic governance. This usage has been deployed by several G20 and global governance scholars, generally to indicate the forum's core role in global economic governance since 2008 [Cooper, 2010, p. 749; Kirton, 2013; Luckhurst, 2012, pp. 741, 769; 2016a, pp. 14171; Narlikar, 2017, p. 8]. This goes beyond a series of isolated summit meetings; rather the G20 summits are the proverbial "tip of the iceberg" of G20-related activities [Alexandroff, Brean, 2015 , p. 10]. The G20 has become a global governance hub in several policy areas beyond its original focus on international economic recovery and financial regulatory reform. This indicates its potential for creative, transversal policy effects by linking these policy agendas. It is a "hub" in the sense that it directs the activities of other international agencies and actors in order to diffuse particular policy norms and practices in global governance.

This "hub" notion is linked to, but distinct from, the G20's role as a "steering committee." In this study, the former, "hub," indicates the forum's substantial influence on policy processes and practices of global economic governance since the GFC; "steering committee" refers to its deliberative and framing functions in managing global issues. There has been much debate about whether the G20 effectively transitioned from a crisis committee to a steering committee following the GFC [Cooper, 2010; 2012; Crump, Downie, 2018; Kirton, 2013; Luckhurst, 2016a; Subacchi, Pickford, 2011]. However, both conceptualizations are compatible with the notion of the G20 as a global governance $h u b$. The G20 has decentralized authority as a crisis committee and steering committee by integrating non-G7 actors into global governance deliberations; ${ }^{2}$ through its policy-hub role it has done so by involving more diverse networks in diffusing and implementing policy processes and practices.

These hub and steering roles have often been emphasized in analyzing the G20's relations with global governance networks, especially how the forum integrates diverse actors and organizations through its policy and engagement processes [Cooper, Thakur, 2013, pp. 134-5; Khanna, 2012, pp. 386-7; Kirton, 2013, p. 16, pp. 35-6; Larionova, 2017, pp. 77-80; Luckhurst, 2012, pp. 741, 769; 2016a, pp. 141-71; Slaughter, 2019, pp. 12-3]. Such networks influence the G20 agenda and other contexts of global governance through their agency and authority.

2 "G7," "G8," and "G7/8" are used in the article due to the different periods under discussion, depending on whether the group included Russia at a particular moment; sometimes both groups are intentionally indicated. The G7 finance ministerial forum mostly excluded Russia even when the latter participated in G8 summits. 
They consist of private, non-state, state, quasi-state, ${ }^{3}$ intergovernmental and supranational actors that contribute to the production of global governance (cf. Sørensen and Torfing [2007, p. 3]). Recent global governance studies incorporating insights from the sociology of professions literature indicate that global governance networks constitute linked professional "ecologies" consisting of actors that cooperate, in particular contexts, by defining the issues, tasks and individual competencies of network members [Seabrooke, 2014, p. 53; see Karlsrud, 2016]. Participant observation, semi-structured interviews and personal discussions with members of such G20 governance networks form part of the research for the present study.

The scholarly literature notes a significant expansion of the types of actors involved in global governance since the 1990s [Dingwerth, Pattberg, 2006; Luckhurst, 2017; Rosenau, 1995]. This has increased the scope of international diplomacy, as diplomats and officials engage with diverse actors that are "in contestation and competition in order to shape discourse and policy" [Cooper, Cornut, 2019, p. 307]. This indicates the importance of public diplomacy, but states are not the only actors to engage in it; rather, transnational advocacy groups and other non-state actors conduct their own forms of public diplomacy to influence policy agendas [Gilboa, 2008, p. 59]. There is evidence of this from G20 members and its transnational policy and governance networks [Slaughter, 2015; 2019; Stone, 2015]. The author of the present article has observed G20 engagement-group participants emphasizing the importance of influencing the G20 agenda through public outreach, including media interviews and public meetings, not just direct lobbying of G20-member representatives. The latter point indicates how G20 and even non-G20 domestic audiences could sway the forum's agenda [see Lenz, 2018; Schirm, 2013], with citizens sometimes passively or actively engaged in global policy debates, especially due to expanding channels of public political discourse via the Internet.

Another key conceptual focus of the present analysis is decentralizing authority. This article, building on previous research [Luckhurst, 2016a; 2017], focuses on three key aspects of authority in global economic governance and specifically the G20 context. These are strategic, political and cognitive authority, and their effects on the organization, policies and actors involved in the G20. The emphasis on these aspects of authority does not exhaust all possible forms, for example one could discuss legal or even "moral" authority; however, focusing on these three dimensions constitutes a useful framework for analyzing the G20's importance for global governance [see Luckhurst, 2016a, pp. 142-6; 2017, pp. 6-10].

There has been a growing emphasis on "authority" and particular forms of it in recent global governance and G20 research [Broome, Seabrooke, 2015; Eccleston, Kellow, Carroll, 2015; Luckhurst, 2016a, 2017; Zürn, 2018]. It is important to stress that "authority" is socially constructed even when legally recognized, and hence "inextricably dependent upon social perception and recognition" [Reus-Smit, 2007, p. 44; see Hopf, 1998, pp. 178-9]. Strategic authority indicates how state or other actors' long-term accrued and durable resources, such as military capacities, gross domestic product, natural resources, technology, education, skills and population influence perceptions of competence to act in a given context. Political authority concerns an actor's perceived and socially constructed, in addition to legally defined, "political rights and responsibilities" [Ruggie, 1982, p. 380]; in other words, the extent to which their activities in particular contexts are considered politically legitimate competencies. Cognitive authority indicates actors' authoritativeness due to their professional standing and perceived access to information, experience, know-how and other cognitive status markers [Broome, Seabrooke, 2015].

${ }^{3}$ The phrases "quasi-state" or "semi-state" are used interchangeably to indicate quasi-autonomous public bodies or government-backed private institutions that provide public services. They exist in various institutional types, generally with ties to the state but not completely subsumed by it. 
It is useful to focus on these aspects of authority when analyzing shifts in the organization, policies and actors of global economic governance and, specifically, the G20. The social construction of authority is particularly relevant in this context due to the G20's lack of formal legal status as an informal forum. This informality of the G20's authority, indicating the absence of institutionalization, brings to mind J. Rosenau's [1992, pp. 2-3] comment that "in a world where authority is undergoing continuous relocation... [it is] imperative to probe how governance can occur in the absence of government."

\section{Decentralizing Global Governance Authority: From the Cold War to the GFC}

The Bretton Woods architecture of global economic governance was greatly influenced by American governments. This was indicated by their financial contributions to the post-war international economic reconstruction, combined with substantial strategic, political and also cognitive authority at the International Monetary Fund (IMF) and World Bank. American leadership of the North Atlantic Treaty Organization (NATO) underpinned its international security capacities, though the United Nations (UN) Security Council was too divided during the Cold War for U.S. military strength to translate into global authority and leadership of security governance.

American international economic influence was considerable throughout the second-half of the 20th century but gradually decreased, in relative terms, especially as the economies of western Europe and Japan expanded. There were economic challenges for U.S. administrations, such as persistent trade deficits from the 1970s onward. Cold War security guarantees to American allies sustained U.S. strategic and political authority among them, despite this declining economic pre-eminence. The conclusion of the Cold War dramatically altered the international context, increasing opportunities for broader multilateral cooperation and genuinely global governance [Rosenau, 1992, p. 1]. F. Fukuyama [1989] famously perceived this moment as the "end of history," arguing that the apparent triumph of liberal democracy had settled, once and for all, the history of competing political orders. This was a hubristic response to these international shifts. The so-called "unipolar moment" thesis of renewed American predominance was similarly exaggerated [see Krauthammer, 1990], ignoring, as it did, continued security threats and the economic significance of the European Union (EU), Asian regional integration, and the fast-growing developing states.

Officials and governments of the G7/8 and Bretton Woods institutions took steps to consolidate the "liberal international order" in the 1990s. This included establishing the World Trade Organization (WTO) and reinforcing global-regional multilateral cooperation through deeper EU integration and membership expansion and the new North American Free Trade Agreement (NAFTA). Expansion of global and regional economic governance and cooperation was reinforced by the increasingly pervasive discourse on economic globalization. This was rhetorically deployed in advocating economic liberalization, including to legitimize policy agendas such as the Washington Consensus [Rodrik, 2006; see Williamson, 1990], reforms prescribed to developing states by G7 governments, the IMF and World Bank.

The Asian financial crisis of 1997-98, plus a series of financial crises in Latin America, undermined confidence in these Washington prescriptions in developing states, with strong critiques also from influential western-based economists and development experts [see Easterly, 2003; Rodrik, 2006; Stiglitz, 2002]. Lessons from the Asian crisis, subsequently augmented by those from the GFC, constituted a "crisis effect" that undermined élite conventional wisdom in development policymaking [see Widmaier, Blyth, Seabrooke, 2007]. This undermining of global governance norms and practices reduced the cognitive authority, especially, of officials 
from G7 states and the Bretton Woods institutions [Ravenhill, 2002, pp. 170-1; Stubbs, 2002, pp. 448-9]. There is substantial evidence that policymakers from leading developing states became more sceptical of policy advice from western-led institutions due to the widely perceived failures of the Washington Consensus and especially the IMF's impact in exacerbating some financial crises through its structural adjustment programmes [Broad, 2004, pp. 133-4; Cooper, 2008, p. 254; Easterly, 2003; Luckhurst, 2017, pp. 156-63; Rajan, 2005; Rodrik, 2012, pp. 90-5; Sohn, 2005, pp. 490-2; Stiglitz, 2003, pp. 245-6; 2004].

World Bank and IMF staff openly contested the significance of the Washington Consensus by the early 2000s. Senior World Bank figures, including J. Stiglitz, condemned the consequences of the "Washington" policy prescriptions, contrary to the reluctance of IMF officials to revise their own institutional position [see IMF, 2002; 2003, p. 6; Rodrik, 2006, p. 977; Rogoff, 2003; Singh et al., 2005; Stiglitz, 2001; World Bank, 2005]. The global political shifts of the 1990s brought enduring organizational adjustments to the global governance architecture even though the development policy evidence became contested. These organizational shifts included new institutional mechanisms, actors and practices of global economic governance. More diverse economic issues were addressed by global governance, plus new forms of cooperation on climate change, the UN Millennium Development Goals and greater focus on issues of gender rights, labour protection and international humanitarian law.

Transnational advocacy groups became more influential, augmenting the global governance focus on these broader issues. The growing influence of transnational and non-state actors, including civil society organizations (CSOs), was partly enabled by new advocacy opportunities, especially due to technologies such as the Internet but also to the growing professionalization and enhanced technical capacities of CSOs [Keck, Sikkink, 1999, pp. 95-9; Price, 2003, p. 584; Scholte, 2004]. CSOs made two crucial global governance interventions in the 1990s, undermining both the Organisation for Economic Co-operation and Development's (OECD) attempts to implement its proposed multilateral agreement on investment [Smythe, 2000] and the IMF leadership's attempts to amend the Fund's articles of agreement to prohibit capital controls [Rodrik, 2012, pp. 90-5]. Policy debates on these issues indicated how non-state actors could influence global governance and in effect compel policy shifts, thus decentralizing authority from states and international financial institutions (IFIs) to non-state actors.

The growing complexity of late 20th century global economic governance involved other nonstate and quasi-state actors. This included the direct governance role of professional standard-setting bodies which, despite being non-governmental agencies, gained significant delegated authority in key decisions on the practices, rules and norms of aspects of global economic governance, given that governments often implement their policy recommendations [Büthe, Mattli, 2011, pp. 220-6]. Growing competition between EU and U.S. professional-standards bodies further indicated at least a partial decentralizing effect in global economic governance, shifting from the mid-20th century predominance of American professional associations, particularly in the context of product standards [Büthe, Mattli, 2011]. Another indicator of growing complexity was the increased significance of financial rating agencies, especially the "big three" of Moody's, Standard \& Poor's and Fitch. Critics attributed substantial blame to them for contributing to the GFC through flawed financial risk models [Rudd, 2009, p. 24; Utzig, 2010, pp. 2-4]. In addition to these non-state organizations, the growing influence of opaque sovereign wealth funds in the early 2000 s contributed to decentralizing authority in managing global investment flows, as their substantial economic influence was beyond the control of G7/8 states and IFIs [Clark, Dixon, Monk, 2013].

The global authority of American policymakers noticeably declined in the first decade of the 21st century due to relative shifts in global economic capacities and for political reasons (see Fig. 1), including the negative perception of the Bush administration's unilateralism, especially as a consequence of the 2003 invasion of Iraq [Nye, 2004]. Global economic governance 
became a particularly significant context of decentralizing authority away from American and G7/8 leadership, partly as a consequence of the growing economic capacities of developing states such as China and India [Luckhurst, 2017]. This shift in the global economic balance accelerated during the GFC in 2008-09 most dramatically because of China's fast-growing economy, as well as some of the other states in the BRICS grouping of Brazil, Russia, India, China and South Africa (see Fig. 2 and 3).

The Asian financial crisis had been the key motivation for establishing the Financial Stability Forum (FSF) and the G20 forum of finance ministers and central bankers in 1999, which paved the way for a G20 leaders' forum by 2008. These new global governance contexts also increased the diversity of actors engaged in global economic governance though, until the GFC, this predominantly took the form of outreach engagement and consultation. This included a series of G8 summits in the early to mid-2000s to which the "Outreach Five" group of leaders from Brazil, China, India, Mexico and South Africa were invited to attend as guests. The bankruptcy of Lehman Brothers' investment bank which sparked the GFC in September 2008 provided the opportunity for the G20 to become a key catalyst for intensifying this integration trend in global economic governance.

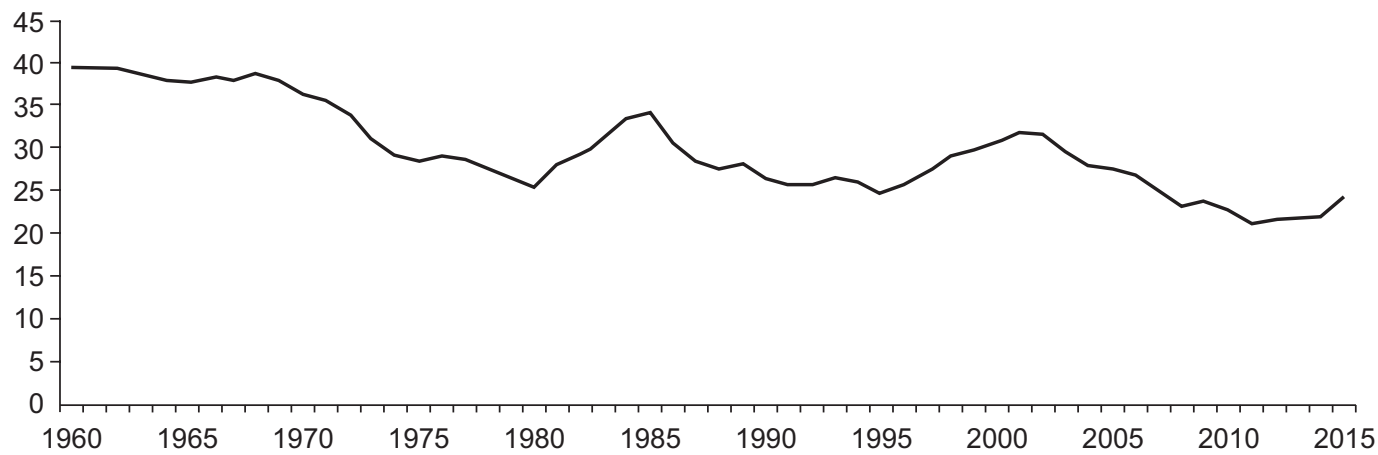

Fig. 1. Percentage Share of World Economic Output, Current Prices, 2017

Source: [The World Bank, n. d.].

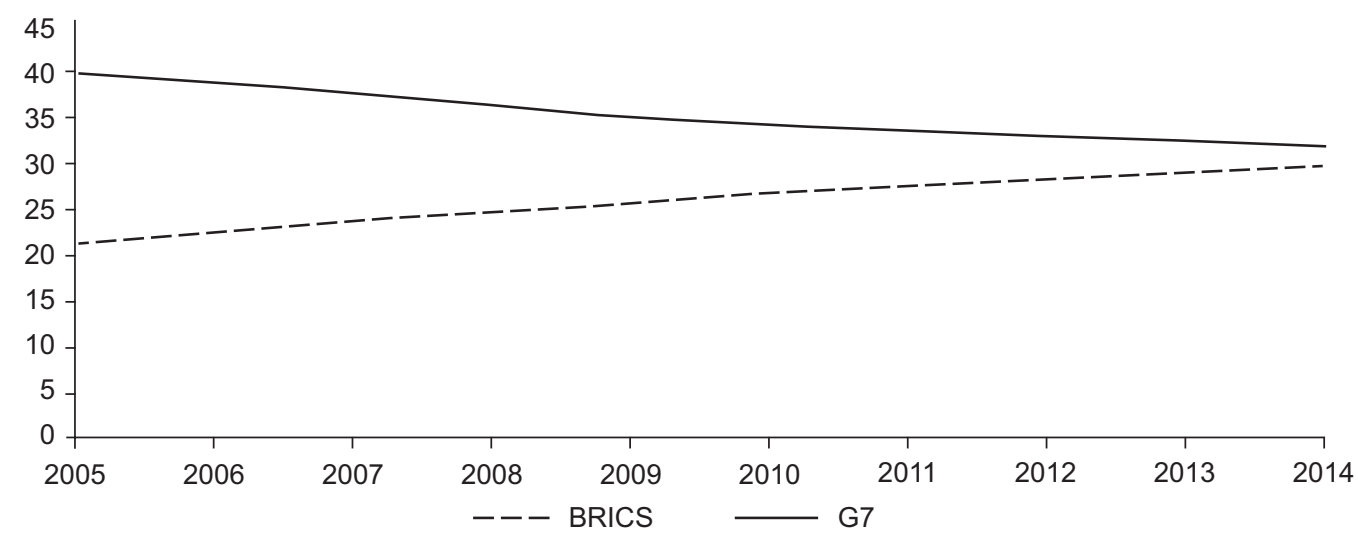

Fig. 2. Gross Domestic Product Based on Purchasing-Power-Parity (PPP) Share of World Total (\%), G7 and BRICS Comparison

Source: [IMF, 2015] (Originally published in Luckhurst [2016a]). 


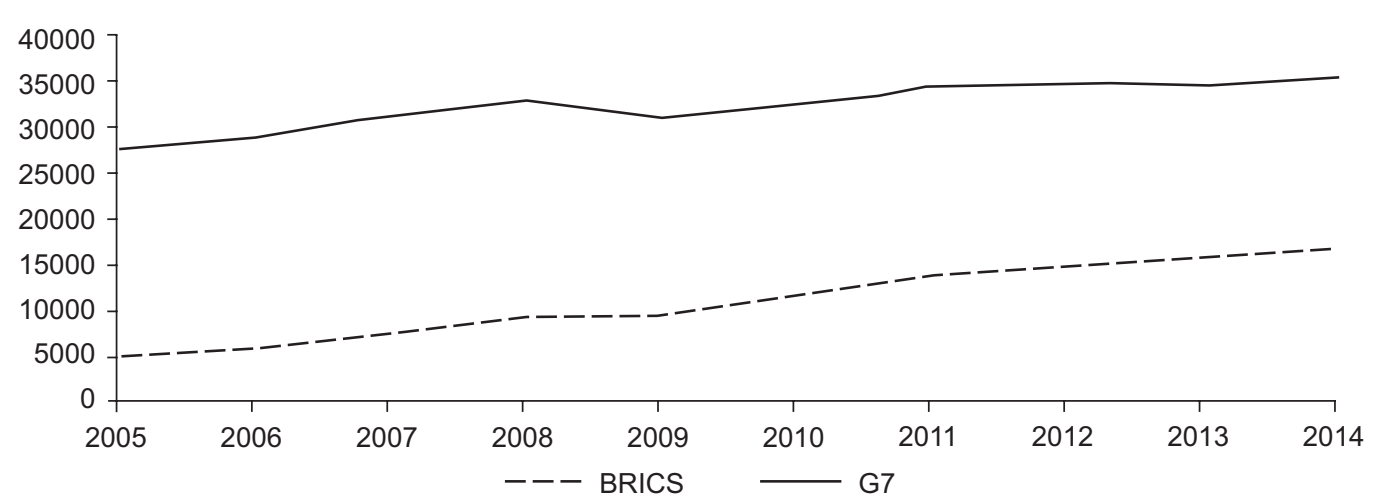

Fig. 3. Gross Domestic Product 2015 Prices (\$ Billion), G7 and BRICS Comparison

Source: [IMF, 2015].

There has been a debate about whether the G20 finance forum was primarily designed to enable leading wealthy states to influence "systemically important" developing states [Cooper, Thakur, 2013, p. 37]. The GFC disrupted the sense of hierarchy in global economic governance as the G20 reacted by integrating leading developing states as more equal partners in global economic governance. The G20 quickly became the focus for multilateral efforts to control the GFC in 2008, with President George W. Bush convening the first G20 summit in Washington DC by November, only two months after the Lehman collapse. The G20 took centre stage despite some calls for the UN to lead [UN, 2008; Wade, 2012]. This was partly due to its flexibility as an informal forum without fixed rules and procedures, which enabled it to be adapted rapidly to the circumstances, including the increasingly evident global authority shifts. Its members also were capable of resolving the crisis due to their combined global authority. A year later, G20 members confirmed it had become their "premier forum for... international economic cooperation” [G20, 2009b].

\section{The G20 Hub of Global Governance Since the GFC}

The GFC constituted what historical institutionalists would call a "critical juncture" for global governance. The G20 contributed substantially to adapting global economic governance to the GFC's political and economic consequences. The integration of leading developing states into key international fora and institutions during the crisis, in addition to the elevation of the G20 to a leader-level forum, indicated the rapid reshaping of global governance to the new context of global political economy.

The economic recovery strategy agreed at the G20's London summit in April 2009 underscored the global authority shifts. The forum brought together a group of 19 states and the EU; half of its members were developing and half wealthy, and they collectively accounted for $85 \%$ of global economic output, two thirds of the world's population and $80 \%$ of global trade. The G20 became a hub for their coordinated response to the GFC, which was unprecedented and impressive in terms of magnitude, scope and outcomes. The London G20 summit included members' agreements to raise their public spending by an additional $2 \%$ of gross domestic product (GDP) and provide \$1.1 trillion in extra funding for the IMF, World Bank and regional multilateral development banks. They further agreed to create a new IFI to monitor global financial stability called the Financial Stability Board (FSB), which effectively institutionalized the informal Financial Stability Forum (FSF) [G20, 2009a]. The G20's entire membership 
was integrated into the Basel Committee for Banking Supervision (BCBS) and the new FSB in 2009. Members' status had already been augmented by creating the leader-level G20, rebranded at its September 2009 Pittsburgh summit as their "premier forum" for global economic governance [G20, 2009b], effectively superseding the leadership role of the G7/8.

The G20's role as a crisis committee and hub of the multilateral GFC response was crucial. The enduring significance of its achievements during this period, especially at the London summit, is sometimes overlooked. It laid the foundations for the G20's subsequent role as the main focus for global economic governance cooperation between its members. Their collective significance for the world economy makes the G20 the most important informal forum for global economic governance. It has also become crucial in other policy areas, contributing to deliberations and sometimes to policy commitments on issues such as climate change, sustainable development, terrorism, health and gender equity. This indicates why its members attach significant importance to their membership. This importance is indicated by the willingness of leaders to attend regular G20 summits, plus the substantial material and human resources committed to G20 engagements, especially from the rotating chair, with multiple G20 ministerial, working group, sherpa and outreach meetings each year.

The perceived failure of the G20 to sustain its initial momentum led to growing doubts about its effectiveness. The declining impact of the GFC by 2010 predictably undermined group cohesion. The two summits that year, held in Toronto in June and Seoul in November, each had important consequences for the future of the G20 but in very different ways. The outcomes of the two summits contrasted significantly, with the Toronto summit subsequently perceived as a low point in G20 cooperation. The divisive discussions in Toronto indicated a shift away from the G20's “crisis committee” sense of solidarity [see Cooper, 2010; Cooper, Thakur, 2013; Kirton, 2013; Luckhurst, 2016a]. This was largely due to growing disagreement on whether to sustain the global fiscal stimulus and economic recovery strategy initiated at the London summit, in light of growing debate about risks from public deficits and debt and apparent improvements in the global economic outlook. The eurozone crisis had begun to spread beyond Greece by the time of the Toronto summit, which led the German government in particular to advocate "fiscal consolidation" through cuts to public expenditure, also known as "austerity" [Luckhurst, 2016b, p. 171, 2017, pp. 97-8; see Blyth, 2013]. This was opposed by the Obama administration, along with the Chinese and several other G20 members which advocated sustaining a progrowth strategy to support the still-fragile global economic recovery [Luckhurst, 2016a, p. 111]. The eurozone crisis and EU austerity policies remained a point of contention between the EU and the U.S. for much of the Obama administration.

The Seoul summit was equally significant for shaping the forum's subsequent role. One important agreement from the Korean G20 presidency was to endorse the soon-to-be-published Basel III Accords on global financial regulation [G20, 2010], concretizing a key aspect of the G20's GFC-period cooperation. Aside from these accords, designed to strengthen the global financial system and prevent a future crisis through the new macroprudential regulatory framework, the Seoul summit had two further important effects. One was to help the G20 recover some momentum, half a year after the failures and fractious disagreements of the Toronto summit. This was significant because a similar outcome in Seoul could have heralded an irreversible decline of the G20's role in global governance. The Seoul summit instead was crucial for recasting the G20 as a post-crisis hub of global governance and an albeit imperfect steering committee. The second key effect was to initiate the diversification of the G20 agenda through the Koreans' inclusion of a focus on economic development. Subsequent host presidencies followed this precedent with the effect of significantly expanding the G20 agenda beyond its crisis-period focus on global economic recovery and financial sector reforms. 
This agenda expansion from the Seoul summit onward had significant consequences for the G20's hub role in global governance. It increased the significance of the G20 as a hub for decentralizing authority, partly because the expanded policy agenda resulted in the inclusion of more actors engaged across a broader range of issues; this also meant diffusing new norms and practices in more policy fields. The forum remains a hub of macroprudential financial reform by continuing to monitor progress on that policy agenda. It is also one hub of global sustainable development governance together with the World Bank and the UN, with the G20 particularly supportive of the UN's 2030 Sustainable Development Goals. The G20's hub role is further reflected in its diversity of policy activities, from its engagement with the BCBS, Bank for International Settlements (BIS), FSB and IMF on the Basel III Accords and the OECD on the Base Erosion and Profit Shifting (BEPS) tax strategy, to its coordination on policy issues such as employment, infrastructure investment, trade, climate change, digitalization and work, gender economic equity, health, migration, aging and demographic shifts. The G20's growing importance in trying to connect these diverse policy contexts indicates an increasingly transversal approach to global governance and constitutes important deliberative-steering and policy effects.

Despite the evidence of more modest achievements from post-GFC G20 summits, especially the absence of such impressive financial inputs as those from the London summit, the forum has contributed to enduring radical shifts in 21 st century global governance. Importantly, the G20's perceived track record of success as a crisis committee [Cooper, 2010, p. 756] would likely make it the obvious, go-to forum for rapidly responding to future global economic crises [Luckhurst, 2016a, p. 263; Narlikar, 2017, p. 4; Subacchi, 2015; Wurf, Sainsbury, 2016]. Recent growing uncertainty and perceived risks to global political and economic stability, with key events such as the UK's "Brexit" referendum of June 2016 and the election of President Donald Trump in November that year, arguably increased the relevance of the G20 as a crisis management forum [Berger, Leininger, Messner, 2017, pp. 113-4; Luckhurst, 2016b].

International organizations (IOs) such as the IMF and OECD cooperate with the G20 because they, like G20 members, recognize the global significance of the forum and also that their own organizational relevance is enhanced by this cooperation. The Independent Evaluation Office (IEO) of the IMF noted this in a report on the IMF's GFC response, including the comments that some members of the IMF's International Monetary and Financial Committee "thought that involvement with the G20 would be helpful for the IMF to build political support, and thus gain greater traction for its policy advice..." and that "involvement with the G20 gave the IMF the opportunity to have its analysis reach the heads of state of the largest economies" [IEO, 2014, p. 6]. This indicates why former IMF managing director D. StraussKahn [2009] agreed to undertake radical policy shifts during the GFC by implementing new policies and standards "in line with the G-20's request that our monitoring include the evolving framework of macroprudential supervision."

IOs that respond to G20 requests to produce proposals in particular policy fields do so in ways that are influenced by their own institutional practices. This is one way that organizations such as the IMF and OECD influence the G20 policy agenda as part of a reciprocal relationship. Their cognitive authority is augmented and reproduced through the G20's recognition of their technical capacities and expertise, enabling them to draft policy documents that the forum endorses. These cognitive authority effects are further increased by the G20's "endorsement function [that] can confer legitimacy on the agendas being promoted by other agencies" [Eccleston, Kellow, Carroll, 2015, p. 300]. One example involved the role of the FSB, IMF and BIS [2011] in designing the Basel III Accords; another was the OECD's influence on the BEPS strategy on tax avoidance. The G20 endorsed the FSB/IMF/BIS proposals for the Basel III Accords at its Seoul summit [G20, 2010] and the OECD's new BEPS guidelines and policy tools at its 2013 St. Petersburg summit [G20, 2013; OECD, 2013]. In both cases, the G20 
requested that the IOs develop policies for implementing the G20's agendas, respectively, on macroprudential regulation and tax avoidance. They complied, but rather than acting as passive institutional followers their influence on the policies was substantial because the IOs designed the detailed policy contents. This is indicative of how the G20 constitutes complex and reciprocal authority effects as a network-hub of global governance, its networked relations including key global governance organizations and officials.

\section{The G20 as a Hub of Decentralizing Authority}

The G20's hub role in global economic governance since the GFC had the effect of concentrating and decentralizing authority while diffusing new policy practices of global economic governance. The first assertion is not contradictory because it indicates how the G20 forum became a focus, or hub, for decentralizing authority in global economic governance.

The G20 contributed to decentralizing authority while decreasing the potential for global governance fragmentation, especially by integrating leading developing states at the heart of global economic governance in its key fora and institutions and through the G20's elevation to a summit-level forum. The process of integration which augmented the authority of G20 developing-state members consequently increased their influence in global governance. This was evident, in strategic authority terms, by the involvement of the developing-state G20 members in its coordinated fiscal and financial response to the GFC; in political authority shifts, by the greater inclusion of developing states in the political agenda-setting bodies of global economic governance; and also in cognitive authority effects, since the G20 and other global governance bodies adjusted their policy agendas during the GFC to positions that more closely reflected priorities of leading developing states such as Brazil, China and India.

One significant consequence of the G20's integration of leading developing states was that it shifted global economic governance norms and practices to include more of those favoured by policy actors from leading developing states. This was further evidence of decentralizing political and cognitive authority. Rather than the anticipated convergence of developing-state economic policy practices with those of leading western states as initially envisaged by the G20 finance forum, the GFC influenced rapid shifts from wealthy G20 members. They adjusted some of their policy norms and practices on issues such as financial regulation and capital controls [Gallagher, 2011; Guha, 2009; IMF, 2009] to match more closely those existing among some East Asian and developing-state members. This was evident in the G20's role in the shift to macroprudential financial regulation and the IMF's more permissive stance on capital controls - which was endorsed by the G20 [G20, 2011]; and by the Korean G20 presidency's success in gaining the forum's consensus in support of its sustainable development agenda [G20, 2010].

These shifts in economic policy practices and norms indicated a further significant issue linked to the declining cognitive authority of officials from leading G7 states such as the UK and the U.S., which was the increased scepticism about market efficiency due to the GFC [Luckhurst, 2017, pp. 87-101]. These ideational and normative shifts certainly altered perceptions of cognitive authority, further indicated by the greater openness of officials and policymakers in questioning economic policy prescriptions of G7 governments and the Bretton Woods institutions. Senior officials from Brazil, China, India and other leading developing states blamed predominantly-western economic policy norms and practices for the GFC. Former U.S. Treasury Secretary H. Paulson [2015, p. 240] noted, for example, that Chinese politician Wang Qishan told him, as a result of the failure of the U.S. financial system in 2008, "[The Chinese] aren't sure we should be learning from you [Americans] anymore." The Brazilian government was equally harsh in its assessment; then Finance Minister Guido Mantega 
asserted, just before the Washington G20 summit of November 2008, that his government refused to be "mere coffee drinkers," implying passive observers, at global governance fora [Partlow, 2008]. His president, Lula da Silva, noted in April 2009, "This crisis was fostered and boosted by irrational behavior of some people that are white, blue-eyed. Before the crisis they looked like they knew everything about economics, and they have demonstrated they know nothing about economics" [Watt, 2009]. Russian policymakers also criticized the role of the American government and financial sector in the GFC. Former President Dmitry Medvedev commented in June 2008, "Failure to take proper account of the risks by the biggest financial companies in combination with an aggressive financial policy by the world's biggest economy led not only to corporate losses. The majority of people on the planet, unfortunately, have become poorer" [Buckley, Belton, 2008].

Representatives from leading developing and non-western states increasingly demanded to be heard and respected as equals in global economic governance. In keeping with this, BRICS stressed the equal, collective ownership of the G20 in a joint declaration prior to the 2014 Brisbane G20 summit, stating "the custodianship of the G20 belongs to all Member States equally and no one Member State can unilaterally determine its nature or character" [Department of International Relations and Cooperation, Republic of South Africa, 2014]. This was in response to speculation about Russia's participation at the Brisbane summit, but it further indicated decentralizing authority in global governance since the diplomatic damage from the suspension of Russia's G8 membership was to some extent offset by diplomatic gains from its BRICS, as well as G20, memberships.

More recently, western influence has been undermined by political-economic problems and sometimes the rejection of multilateralism, even from the UK and American governments. The Brexit negotiations and President Trump's willingness to question established multilateral institutions, norms and practices, especially concerning trade, continue to undermine the global governance authority of the UK and U.S. governments [Luckhurst, 2017, pp. 135-6]. This further signals the shift in global governance authority, especially as Chinese president Xi Jinping [WEF, 2017] has attempted to present himself by way of contrast as a defender of multilateralism and global governance norms and practices.

Some scholars emphasize the importance of the rotating chair in guiding the G20 agenda [Crump, Downie, 2018]. The host presidency plays a key role, though its effectiveness at delivering G20 policy agreements is improved by effectively balancing between agenda control and facilitating deliberation to reach agreements, including through diplomacy with G20 "Troika" partners, other G20 members, non-member states and non-state actors involved in engagement processes [Crump, Downie, 2018, pp. 33-4, 39]. ${ }^{4}$ The hosting in itself constitutes a means for decentralizing global governance authority, considering the non-G7/8 and developing-state members that have held the role. This put the international spotlight on the Korean, Mexican, Australian, Turkish, Chinese and Argentinian host presidencies, boosting their agenda-setting influence, and hence authority, in post-crisis global economic governance. This augmented authority included their relations with intergovernmental organizations; the Chinese government even received support from the OECD in preparing its G20 presidency agenda despite not being an OECD member [Kirton, 2016, p. 101].

Stewardship of the rotating G20 chair has the potential to enhance the host's international reputation. Particularly for developing-state members, also non-G7 wealthy states such as Australia [Harris, Rimmer, 2015], chairing the leader-level G20 significantly increased their oppor-

${ }^{4}$ The G20 "Troika" model of coordination, through consultations between the previous, present and next host presidency, is based on the system introduced by the G20 finance forum in 2002 [Kirton, 2013, pp. 138-40]. 
tunities to be centre stage of international diplomacy and to sway the global governance agenda, thus indicating a significant decentralizing authority effect. The Korean, Mexican, Russian, Australian, Turkish, Chinese and Argentine rotating presidencies indicated how non-G7 states could influence the G20 agenda by focusing on topics relevant to them and the wider world. This involved them expanding the G20 agenda to incorporate sustainable development, food security, employment and employability issues, infrastructure, female labour participation and the future of work in an era of growing digitalization [OECD, 2018]. One priority issue for the Argentinians was gender economic equity, which built on the Australian, Turkish, Chinese and German G20 presidencies' agendas on narrowing the gender gap in labour participation. This indicated how continuity could be achieved between the objectives of developing and wealthy G20 members, aided by the G20 Troika framework [Berger, Leininger, Messner, 2017; Harris Rimmer, 2015].

This agenda diversification constituted a further significant consequence which increased the G20's decentralizing authority through expanded chairing opportunities. The host presidency contributes to a kind of "Christmas tree" effect [Ye, 2014, p. 28] in which they include predecessors' priority agenda items while adding their own to decorate the agenda "tree." This has contributed to the expansion of the G20 agenda as a normative effect of the Troika and rotating-presidency system. More than one G20 sherpa has noted in private comments to the author that this is diplomatically perceived as showing respect for previous presidencies' work. ${ }^{5}$

Other long-term benefits could be gained from public diplomacy opportunities, including from hosting the engagement group meetings. The author of this article conducted research through participant observation and semi-structured interviews at the Buenos Aires Think20 (T20) summit of September 2018 during the Argentine G20 presidency. This indicated that despite dealing with a domestic financial crisis during their host year, the Macri administration put substantial diplomatic effort into the engagement processes. The president attended and gave speeches at the official engagement group summits, plus a number of Argentine government representatives were present, some actively communicating with participants over days of meetings. These outreach activities could hold long-term diplomatic benefits for G20 chairs, especially considering the growing significance of networking in global governance. It constitutes a form of decentralizing authority, giving non-G7 members rare opportunities to conduct public diplomacy on "home turf" while amplifying their diplomatic outreach through G20 leadership and hosting functions.

The G20 has integrated diverse actors and organizations into its policy deliberations and processes. In addition to intergovernmental bodies, the forum has brought non-G20 states into its policy deliberations, especially the Global Governance Group ("3G") of states led by Singapore, which arguably helps to reduce the perception of a "legitimacy gap" in the G20's global governance role [Cooper, Thakur, 2013, pp. 95-7]. Non-state actors have also been incorporated into its policy deliberations, especially through its official outreach engagement forums, currently the Business20 (B20), Civil20 (C20), Labour20 (L20), Science20 (S20), T20, Urban20 (U20), Women20 (W20) and Youth20 (Y20). These include diverse non-state actors such as influential business executives, civil society advocacy-group members, trade unionists, scientists, municipal leaders, academics and think tank experts. They collectively contribute to G20 policy debates by presenting policy briefs to the forum but also more importantly through interpersonal communications and by constituting G20-linked global governance networks that try to sway its policy agenda. Examples include how IFI officials and other advocates of macroprudential financial regulation influenced the G20 agenda during the GFC [Luckhurst, 2016a,

${ }^{5}$ The author's interviews and private discussions with G20-member sherpas, between 2015 and 2018. 
pp. 149-56], Oxfam's influence on the Mexican G20 presidency's development policy agenda [Luckhurst, 2016a, p. 114] and the W20's emphasis on sustaining pressure on the G20 to match its gender-mainstreaming rhetoric, including its " 25 by 25 " target for reducing the gender labour participation gap [W20, 2019].

These further indicate how such G20 governance networks constitute linked professional ecologies consisting of diverse types of actors that, partly because of their diversity, contribute to a more transversal approach to global policy issues. These networks sometimes contribute to G20 policy convergence, especially on technical issues that are less politically contested. This is sometimes reinforced by transnational "epistemic arbitrage" [Seabrooke, 2014], indicating how transnational experts such as those integrated into G20 governance networks are relatively unconstrained by established domestic organizational hierarchies and professional practices due to the "thinness" of transnational professional socialization [Seabrooke, 2014, pp. 50-1, 54-6]. Policy contestation from global governance networks further indicates, in this sense, decentralizing authority by reducing domestic organizational constraints on network actors.

The G20's role as a hub of global governance networks augments its governance capacities through access to broader feedback and policy expertise while further contributing to decentralizing authority in global economic governance [G20, 2013, p. 26, 2014; Luckhurst, 2016a, pp. 199-200; 2017, pp. 64, 68]. This involves a significant expansion in the types of actors involved, especially the integration of non-state actors such as CSOs and non-governmental experts. A further significant effect of decentralizing global governance authority, particularly through G20 engagement with non-state actors, is to increase the forum's transparency and public accountability, thus potentially increasing its perceived legitimacy among citizens [Harris Rimmer, 2015; Kotzian, Kohler-Koch, 2015, pp. 7-8; Luckhurst, 2016a, p. 200; Slaughter, 2013]. This indicates that while concerns about the limitations of the G20's official engagement processes should not be taken lightly [see Clapp, Murphy, 2013, pp. 135-6; Larionova, 2012, p. 4], the engagement fora potentially play a significant role in connecting governments to civil society actors and citizens. The engagement groups could benefit from conducting more of their own public outreach, partly to enhance public engagement with the G20, but also considering the ambiguity of their own legitimacy as global governance actors.

\section{Conclusion}

The GFC was the catalyst for the G20's elevation to a leader-level forum, with significant and enduring effects on global economic governance. One key consequence was that the G20 became a hub for decentralizing strategic, political and cognitive authority in global governance as part of its role in diffusing economic as well as other policy norms and practices. This has substantially influenced the organization, policies and actors of global governance since 2008 .

Four key points are evident from analyzing the G20's role since the GFC. One is that it contributes substantially to decentralizing authority in global economic governance, most obviously by decreasing the relative influence of the G7/8 and increasing the influence of leading developing states and others outside the G7/8. Another is that it further decentralizes authority by integrating diverse global governance networks, involving state, intergovernmental, quasistate and non-state actors in its policy processes. The third point is that the collective global authority of the G20 remains a key attribute sustaining its steering and hub roles in important policy areas despite sometimes modest achievements of recent summit agreements. The fourth is that the G20's initial success as a crisis committee underpins its authority since it gained sufficient prestige to retain its role as the members' premier forum for post-GFC global economic governance. 
The G20's global governance influence is sometimes considered to be waning, especially since 2010. This article indicates instead that it has become an established hub and imperfect steering committee for global economic governance. It continues to contribute to decentralizing authority in global governance, facilitating the adaptation of the latter to the consequences of long-term political and economic shifts. Perceptions are important, and as the most authoritative hub of contemporary global economic governance the G20 remains the obvious choice for managing future global economic crises as a crisis committee-in-waiting.

\section{References}

Alexandroff A.S., Brean D.J.S. (2015) Global Summitry: Its Meaning and Scope Part One. Global Summitry, vol. 1, no 1, pp. 1-26.

Berger A., Leininger J., Messner D. (2017) The G20 in 2017: Born in a Financial Crisis - Lost in a Global Crisis? Global Summitry, vol. 3, no 2, pp. 110-23.

Blyth M. (2013) Austerity: The History of a Dangerous Idea. New York: Oxford University Press.

Broad R. (2004) The Washington Consensus Meets the Global Backlash: Shifting Debates and Policies. Globalizations, vol. 1, no 2, pp. 129-54.

Broome A., Seabrooke L. (2015) Shaping Policy Curves: Cognitive Authority in Transnational Capacity Building. Public Administration, vol. 93, no 4, pp. 956-72.

Buckley N., Belton C. (2008) Medvedev Blames US for Financial Crisis. Financial Times, 7 June. Available at: https://www.ft.com/content/a5e38aaa-34bf-11dd-a47c-0000779fd2ac (accessed 11 February 2019).

Büthe T., Mattli W. (2011) The New Global Rulers: The Privatization of Regulation in the World Economy. Princeton: Princeton University Press.

Clapp J., Murphy S. (2013) The G20 and Food Security: A Mismatch in Global Governance? Global Policy, vol. 4, no 2, pp. 129-38.

Clark G., Dixon A., Monk A. (2013) Sovereign Wealth Funds: Legitimacy, Governance, and Global Power. Princeton: Princeton University Press.

Cooper A.F. (2008) Executive but Expansive: The L20 as a Project of "New" Multilateralism and "New" Regionalism. Regionalisation and Global Governance: The Taming of Globalisation? (A.F. Cooper, C.W. Hughes, P. de Lombaerde (eds)). Abingdon: Routledge.

Cooper A.F. (2010) The G20 As an Improvised Crisis Committee and/or a Contested "Steering Committee" for the World. International Affairs, vol. 86, no 3, pp. 741-57.

Cooper A.F. (2012) The G20 as the Global Focus Group: Beyond the Crisis Committee/Steering Committee Framework. Centre for International Governance Innovation (CIGI). Available at: https://www.cigionline. org/articles/g20-global-focus-group-beyond-crisis-committeesteering-committee-framework (accessed 11 February 2019).

Cooper A.F., Cornut J. (2019) The Changing Practices of Frontline Diplomacy: New Directions for Inquiry. Review of International Studies, vol. 45, no 2, pp. 300-19.

Cooper A.F., Thakur R. (2013) The Group of Twenty (G20). New York: Routledge.

Crump L., Downie C. (2018) The G20 Chair and the Case of the Global Economic Steering Committee. Global Society, vol. 32, no 1, pp. 23-46.

Department of International Relations and Cooperation, Republic of South Africa (2014) Chairperson's Statement on the BRICS Foreign Ministers Meeting Held on 24 March 2014 in The Hague. Available at: http:// www.dirco.gov.za/docs/2014/brics0324.html (accessed 12 February 2017).

Dingwerth K., Pattberg P. (2006) Global Governance as a Perspective on World Politics. Global Governance, vol. 12, pp. 185-206. 
Easterly W. (2003) IMF and World Bank Structural Adjustment Programs and Poverty. Managing Currency Crises in Emerging Markets (M.P. Dooley, J.A. Frankel (eds)). Chicago: University of Chicago Press.

Eccleston R., Kellow A., Carroll P. (2015) G20 Endorsement in Post Crisis Global Governance: More Than a Toothless Talking Shop? British Journal of Politics and International Relations, vol. 17, pp. 298-317.

Financial Stability Board (FSB), International Monetary Fund (IMF), Bank for International Settlements (BIS) (2011) Macroprudential Policy Tools and Frameworks. Progress Report to G20. Available at: https:// www.imf.org/external/np/g20/pdf/102711.pdf (accessed 5 October 2018).

Fukuyama F. (1989) The End of History? The National Interest, vol. 16, pp. 3-18.

Group of 20 (G20) (2009a) Leaders' Statement. London, 2 April. Available at: http://www.g20.utoronto. ca/2009/2009communique0402.pdf (accessed 29 March 2019).

Group of 20 (G20) (2009b) Leaders' Statement. Pittsburgh, 24-25 September. Available at: http://www.g20. utoronto.ca/2009/2009communique0925.html (accessed 29 March 2019).

Group of 20 (G20) (2010) Leaders' Declaration. Seoul, 12 November. Available at: http://www.g20.utoronto. ca/2010/g20seoul.html (accessed 29 March 2019).

Group of 20 (G20) (2011) G20 Coherent Conclusions for the Management of Capital Flows Drawing on Country Experiences as Endorsed by G20 Finance Ministers and Central Bank Governors. Available at: https:// www.mofa.go.jp/policy/economy/g20_summit/2011/pdfs/annex05.pdf (accessed 29 March 2019).

Group of 20 (G20) (2013) Leaders' Declaration. St. Petersburg, 6 September. Available at: http://www.g20. utoronto.ca/2013/2013-0906-declaration.html (accessed 29 March 2019).

Group of 20 (G20) (2014) G20 Leaders' Communiqué. Brisbane, 15-16 November. Available at: http://www. g20.utoronto.ca/2014/2014-1116-communique.html (accessed 29 March 2019).

Gallagher K. (2011) Regaining Control? Capital Controls and the Global Financial Crisis. PERI Working Paper No 250, Political Economy Research Institute. Available at: https://www.peri.umass.edu/publication/ item/download/312_ff3b761e2d45edcbb4323bf2f2a910f (accessed 27 May 2019).

Gilboa E. (2008) Searching for a Theory of Public Diplomacy. The Annals of the American Academy of Political and Social Science, vol. 616, no 1, pp. 55-77.

Guha K. (2009) IMF Refuses to Rule Out Capital Controls. Financial Times, 2 November. Available at: https://www.ft.com/content/80201cce-c7ef-11de-8ba8-00144feab49a (accessed 5 October 2018).

Harris Rimmer S. (2015) A Critique of Australia's G20 Presidency and the Brisbane Summit 2014. Global Summitry, vol. 1, no 1, pp. 41-63.

Hopf T. (1998) The Promise of Constructivism in International Relations Theory. International Security, vol. 23, no 1, pp. 171-200.

Independent Evaluation Office (IEO) (2014) IMF Response to the Financial and Economic Crisis. Evaluation Report: Independent Evaluation Office of the IMF. Available at: https://ieo.imf.org/en/our-work/evaluationreports/Completed/2014-1027-imf-response-to-the-financial-and-economic-crisis (accessed 10 April 2019).

International Monetary Fund (IMF) (2002) An Open Letter to Joseph Stiglitz, by Kenneth Rogoff, Economic Counsellor and Director of the Research Department, IMF. IMF Views and Commentaries, 2 July. Available at: https://www.imf.org/en/News/Articles/2015/09/28/04/54/vc070202 (accessed 27 June 2017).

International Monetary Fund (IMF) (2003) The IMF and Recent Capital Account Crises: Indonesia, Korea, Brazil. Evaluation Report. Available at: https://www.imf.org/external/np/ieo/2003/cac/pdf/all.pdf (accessed 27 June 2017).

International Monetary Fund (IMF) (2009) IMF Completes First Review Under Stand-By Arrangement With Iceland, Extends Arrangement, and Approves US\$167.5 Million Disbursement. Press Release No 09/375, 28 October. Available at: http://www.imf.org/external/np/sec/pr/2009/pr09375.htm (accessed 5 October 2018).

International Monetary Fund (IMF) (2015) World Economic Outlook Database. Available at: http://www.imf. org/external/pubs/ft/weo/2015/01/weodata/download.aspx (accessed 5 October). 
Karlsrud J. (2016) Norm Change in International Relations: Linked Ecologies in UN Peacekeeping Operations. New York: Routledge.

Keck M.E., Sikkink K. (1999) Transnational Advocacy Networks in International and Regional Politics. International Social Science Journal, vol. 51, no 159, pp. 89-101.

Khanna P. (2012) How Multi-Stakeholder Is Global Policy? Global Policy, vol. 3, no 3, pp. 384-90.

Kirton J.J. (2013) G20 Governance for a Globalized World. Farnham: Ashgate Publishing.

Kirton J.J. (2016) China's G20 Leadership. New York: Routledge.

Kotzian P., Kohler-Koch B. (2015) Holding International Governance to Account: Do Civil Society Organizations Have a Chance to Exert Accountability? Journal of International Organizations Studies, vol. 6, no 2, pp. 5-26.

Krauthammer C. (1990) The Unipolar Moment. Foreign Affairs, vol. 70, no 1, pp. 23-33.

Larionova M. (2012) From the Mexican to the Russian G20 Presidency. Global Perspective: G20 Update, Higher School of Economics. Available at: https://publications.hse.ru/mirror/pubs/share/folder/jax65qrtlp/ direct/63020446 (accessed 5 October 2018).

Larionova M. (2017) G20: Engaging With International Organizations to Generate Growth. International Organisations Research Journal, vol. 12, no 2, pp. 54-86.

Lenz H. (2018) Achieving Effective International Cooperation: How Institutional Formalization Shapes Intergovernmental Negotiations. World Affairs, vol. 181, no 2, pp. 161-80.

Luckhurst J. (2012) The G20 and Ad Hoc Embedded Liberalism: Economic Governance Amid Crisis and Dissensus. Politics \& Policy, vol. 40, no 5, pp. 740-82.

Luckhurst J. (2016a) G20 Since the Global Crisis. New York: Palgrave Macmillan.

Luckhurst J. (2016b) The G20's Growing Political and Economic Challenges. Global Summitry, vol. 2, no 2, pp. 161-79.

Luckhurst J. (2017) The Shifting Global Economic Architecture: Decentralizing Authority in Contemporary Global Governance. New York: Palgrave Macmillan.

Narlikar A. (2017) Can the G20 Save Globalisation? GIGA Focus Global No 1, German Institute of Global and Area Studies. Available at: https://nbn-resolving.org/urn:nbn:de:0168-ssoar-51669-5 (accessed 27 May 2019).

Nye J.S. (2004) The Decline of America's Soft Power. Foreign Affairs, vol. 83. Available at: http://heinonline. org/HOL/LandingPage?handle=hein.journals/fora83\&div=43\&id=\&page (accessed 27 June 2017).

Organisation for Economic Co-operation and Development (OECD) (2013) Action Plan on Base Erosion and Profit Shifting. Paris: OECD. Available at: https://www.oecd.org/ctp/BEPSActionPlan.pdf (accessed 27 June 2017).

Organisation for Economic Co-operation and Development (OECD) (2018). Bridging the Digital Gender Divide: Include, Upskill, Innovate. Paris: OECD. Available at: http://www.oecd.org/internet/bridging-thedigital-gender-divide.pdf (accessed 10 April 2019).

Partlow J. (2008) Brazil's Lula Urges “Global Solutions.” Washington Post, 27 June. Available at: http://www. washingtonpost.com/wp-dyn/content/article/2008/11/08/AR2008110801329.html (accessed 27 June 2017).

Paulson H. (2015) Dealing With China: An Insider Unmasks the New Economic Superpower. New York: Hachette Book Group.

Price R. (2003) Transnational Civil Society and Advocacy in World Politics. World Politics, vol. 55, pp. 579606.

Rajan R.G. (2005) Has Financial Development Made the World Riskier? NBER Working Paper No 11728, National Bureau of Economic Research. Available at: http://www.nber.org/papers/w11728 (accessed 17 February 2017).

Ravenhill J. (2002) A Three Bloc World? The New East Asian Regionalism. International Relations of the AsiaPacific, vol. 2, no 2, pp. 167-95. 
Reus-Smit C. (2007) International Crises of Legitimacy. International Politics, vol. 44, no 2-3, pp. 157-74.

Rodrik D. (2006) Goodbye Washington Consensus, Hello Washington Confusion? Journal of Economic Literature, vol. 44, no 4, pp. 973-87.

Rodrik D. (2012) The Globalization Paradox: Why Global Markets, States, and Democracy Can't Coexist. Oxford: Oxford University Press.

Rogoff K. (2003) The IMF Strikes Back. IMF Views and Commentaries, 10 February. Available at: https:// www.imf.org/en/News/Articles/2015/09/28/04/54/vc021003 (accessed 27 June 2017).

Rosenau J.N. (1992) Governance, Order, and Change in World Politics. Governance Without Government: Order and Change in World Politics (J.N. Rosenau, O.-E. Czempiel (eds)). Cambridge: Cambridge University Press, pp. 1-29.

Rosenau J.N. (1995) Governance in the Twenty-First Century. Global Governance, vol. 1, pp. 13-43.

Rudd K. (2009) The Global Financial Crisis. Australian Politics, Society \& Culture: The Monthly. February, pp. 20-9. Available at: https://www.themonthly.com.au/issue/2009/february/1319602475/kevin-rudd/globalfinancial-crisis (accessed 19 November 2016).

Ruggie J.G. (1982) International Regimes, Transactions, and Change: Embedded Liberalism in the Postwar Economic Order. International Organization, vol. 36, no 2, pp. 379-415.

Schirm S.A. (2013) Global Politics Are Domestic Politics: A Societal Approach to Divergence in the G20. Review of International Studies, vol. 39, no 3, pp. 685-706.

Scholte J.A. (2004) Civil Society and Democratically Accountable Global Governance. Government and Opposition, vol. 39, no 2, pp. 211-33.

Seabrooke L. (2014) Epistemic Arbitrage: Transnational Professional Knowledge in Action. Journal of Professions and Organization, vol. 1, no 1, pp. 49-64.

Singh A., Belaisch A., Collyns C., de Masi P., Krieger R., Meredith G., Rennhack R. (2005) Stabilization and Reform in Latin America: A Macroeconomic Perspective on the Experience Since the Early 1990s. IMF Occasional Paper 238, International Monetary Fund. Available at: http://www.imf.org/external/pubs/ft/op/238/ (accessed 27 June 2017).

Slaughter S. (2013) The Prospects of Deliberative Global Governance in the G20: Legitimacy, Accountability, and Public Contestation. Review of International Studies, vol. 39, no 1, pp. 71-90.

Slaughter S. (2015) Building G20 Outreach: The Role of Transnational Policy Networks in Sustaining Effective and Legitimate Summitry. Global Summitry, vol. 1, no 2, pp. 171-86.

Slaughter S. (2019) Interpreting Civil Society Engagement With the G20: The Qualified Inclusion of the 2014 Civil 20 Process. Globalizations, vol. 16, no 1, pp. 36-49.

Smythe E. (2000) State Authority and Investment Security: Non-State Actors and the Negotiation of the Multilateral Agreement on Investment at the OECD. Non-State Actors and Authority in the Global System (R.A. Higgott, G.R.D. Underhill, A. Bieler (eds)). New York: Routledge.

Sohn I. (2005) Asian Financial Cooperation: The Problem of Legitimacy in Global Financial Governance. Global Governance, vol. 11, no 4, pp. 487-504.

Sørensen E., Torfing J. (2007) Introduction: Governance Network Research: Toward a Second Generation. Theories of Democratic Network Governance (E. Sørensen, J. Torfing, J. (eds)). Basingstoke and New York: Palgrave Macmillan.

Stiglitz J.E. (2001) Failure of the Fund. Rethinking the IMF Response. Harvard International Review, vol. 23, no 2, pp. 14-8.

Stiglitz J.E. (2002) Participation and Development: Perspectives From the Comprehensive Development Paradigm. Review of Development Economics, vol. 6, no 2, pp. 163-82.

Stiglitz J.E. (2003) Globalization and the Logic of International Collective Action: Re-Examining the Bretton Woods Institutions. Governing Globalization: Issues and Institutions (D. Nayyar (ed.)). Oxford: Oxford University Press. 
Stiglitz J.E. (2004) Capital-Market Liberalization, Globalization, and the IMF. Oxford Review of Economic Policy, vol. 20, no 1, pp. 57-71.

Stone D. (2015) The Group of 20 Transnational Policy Community: Governance Networks, Policy Analysis and Think Tanks. International Review of Administrative Sciences, vol. 81, no 4, pp. 793-811.

Strauss-Kahn D. (2009) Beyond the Crisis: Sustainable Growth and a Stable International Monetary System. Speech by Dominique Strauss- Kahn, Managing Director of the International Monetary Fund, at the Sixth Annual Bundesbank Lecture, 4 September. Available at: https://www.imf.org/external/np/speeches/2009/090409.htm (accessed 30 March 2019).

Stubbs R. (2002) ASEAN Plus Three: Emerging East Asian Regionalism? Asian Survey, vol. 42, no 3, pp. 440-55.

Subacchi P. (2015) Is the G-20 Still the World's Crisis Committee? Foreign Policy, 25 November. Available at: https://www.yahoo.com/news/g20-still-world-crisis-committee-203322118.html (accessed 30 March 2019).

Subacchi P., Pickford S. (2011) Legitimacy vs Effectiveness for the G20: A Dynamic Approach to Global Economic Governance. Chatham House Briefing Paper, October. Available at: https://www.chathamhouse. org/sites/files/chathamhouse/1011bp_subacchi_pickford.pdf (accessed 27 June 2017).

United Nations (UN) (2008) Transcript of Press Conference by Secretary-General Ban Ki-Moon at United Nations Headquarters, 11 November. Press Release. Available at: https://www.un.org/press/en/2008/ sgsm11916.doc.htm (accessed 19 September 2015).

Utzig S. (2010) The Financial Crisis and the Regulation of Credit Rating Agencies: A European Banking Perspective. ADBI Working Paper Series No 188, Asian Development Bank Institute. Available at: https://papers. ssrn.com/sol3/papers.cfm?abstract_id=1592834\#\# (accessed 19 September 2015).

Women 20 (W20) W20 Japan 2019 Communiqué. Tokyo, March 23. Available at: https://w20japan.org/en/ pdf/w20_communique_en.pdf (accessed 11 April 2019).

Wade R. (2012) The G192 Report. Le Monde Diplomatique, August. Available at: http://mondediplo. com/2012/08/09un (accessed 11 April 2019).

Watt N. (2009) "Blue-Eyed Bankers" to Blame for Crash, Lula Tells Brown. The Guardian, 26 March. Available at: https://www.theguardian.com/world/2009/mar/26/lula-attacks-white-bankers-crash (accessed 19 September 2015).

Widmaier W., Blyth M., Seabrooke L. (2007) Exogenous Shocks or Endogenous Constructions? The Meanings of Wars and Crises. International Studies Quarterly, vol. 51, no 4, pp. 747-59.

Williamson J. (1990) What Washington Means by Policy Reform. Latin American Readjustment: How Much Has Happened (J. Williamson (ed.)). Washington DC: Institute for International Economics.

World Bank (2005) Economic Growth in the 1990s: Learning From a Decade of Reform. Available at: https:// openknowledge.worldbank.org/handle/10986/7370 (accessed 5 October 2018).

World Bank (n. d.) World Bank Database. Available at: http://data.worldbank.org/indicator/NY.GDP.MKTP. CD?locations=US-1W (accessed 26 June 2017).

Wurf H., Sainsbury T. (2016) Making the Most of the G20. Lowy Institute Analyses, 29 July. Available at: https://www.lowyinstitute.org/publications/making-most-g20 (accessed 11 February 2019).

World Economic Forum (WEF) (2017) President Xi's Speech to Davos in Full. World Economic Forum. Davos, 17 January. Available at: https://www.weforum.org/agenda/2017/01/full-text-of-xi-jinping-keynote-atthe-world-economic-forum (accessed 11 February 2019).

Ye Y. (2014) A Reflection on the G20: From Strategic to Pragmatic. G20 Monitor No 15, G20 Studies Centre, Lowy Institute for International Policy.

Zürn M. (2018) A Theory of Global Governance: Authority, Legitimacy, and Contestation. Oxford: Oxford University Press. 


\title{
«Группа двадцати» как хаб децентрализации влияния в глобальном управлении ${ }^{1}$
}

\author{
Дж. Лакхерст
}

Лакхерст Джонатан - PhD, доцент по международным отношениям Высшей школы международных исследований мира Университета Сока; Japan, Tokyo, 192-8577, Hachioji, Tangi-machi, 1-236; E-mail: luckhurst@ soka.ac.jp

В статье рассматривается, как «Группа двадцати» стала хабом децентрализации влияния в глобальном экономическом управлении после глобального финансового кризиса 2008-2009 гг. Анализируется, как форум отреагировал на кризис, децентрализовав влияние «Группы семи/восьми» и включив новых участников и сети в глобальное управление. «Двадцатка» также стала важным центром распространения новых политических норм и практик. Эти последствия глобального кризиса связаны с изменениями международного влияния после холодной войны. Аналитический подход объединяет, в частности, инструменты социального конструктивизма в области международных отношений и подходы литературы по социологии профессий. Он включает в себя анализ стратегических, политических и когнитивных аспектов влияния и акиент на воздействии сетей глобального управления на политические процессы и практики в рамках «Группы двадиати». Исследование основано на включенном наблюдении, полуструктурированных интервью и личных беседах с участниками таких сетей управления в рамках «двадиатки». Показано, как роль «руппы двадцати» в качестве движущей силы и проводника изменений в мировом влиянии была усилена глобальным финансовым кризисом.

Ключевые слова: «Группа двадцати»; хаб; глобальное управление; влияние

Для цитирования: Лакхерст Дж. (2019) «Группа двадцати» как хаб децентрализации влияния в глобальном управлении // Вестник международных организаций. Т. 14. № 2. С. 7-30 (на русском и английском языках). DOI: 10.17323/1996-7845-2019-02-01

\section{Источники}

Группа двадцати (2009а) Питтсбургский саммит - заявление глав государств «Группы двадцати». Режим доступа: https://www.ranepa.ru/images/News_ciir/Project/G20_new_downloadings/Pittsburg_2009_ RUS.pdf (дата обращения: 27.05.2019).

Группа двадцати (2009b) План действий по выходу из глобального финансового кризиса. Режим доступа: https://www.ranepa.ru/images/News_ciir/Project/G20_new_downloadings/FIN_CRISIS_PLAN_ 2009.pdf (дата обращения: 27.05.2019).

Группа двадцати (2010) Декларация саммита «Группы двадцати» в Сеуле. Режим доступа: https://www. ranepa.ru/images/News_ciir/Project/G20_new_downloadings/Seoul_2010_RUS.pdf (дата обращения: 27.05. 2019).

Группа двадцати (2013) Санкт-Петербургская декларация лидеров «Группы двадцати». Режим доступа: https://www.ranepa.ru/images/News_ciir/Project/G20_new_downloadings/S-PETERBURG_2013_ RUS.pdf (дата обращения: 27.05.2019).

Группа двадцати (2014) Коммюнике лидеров «Группы 20» по итогам саммита в Брисбене. Режим доступа: https://www.ranepa.ru/images/media/g20/2014brisbane/Kommiunike_liderov_Gruppy_dvadtsati_po_ itogam.pdf (дата обращения: 27.05.2019).

Ларионова М.В. (2017) «Группа двадцати» и международные организации: взаимодействие для обеспечения сильного, устойчивого и сбалансированного роста // Вестник международных организаций. T. 12. № 2. C. 54-86. DOI: 10.17323/1996-7845-2017-02-54.

\footnotetext{
${ }^{1}$ Статья поступила в редакцию в феврале 2019 г.
} 
Alexandroff A.S., Brean D.J.S. (2015) Global Summitry: Its Meaning and Scope Part One // Global Summitry. Vol. 1. No. 1. P. 1-26.

Berger A., Leininger J., Messner D. (2017) The G20 in 2017: Born in a Financial Crisis - Lost in a Global Crisis? // Global Summitry. Vol. 3. No. 2. P. 110-23.

Blyth M. (2013) Austerity: The History of a Dangerous Idea. New York: Oxford University Press.

Broad R. (2004) The Washington Consensus Meets the Global Backlash: Shifting Debates and Policies // Globalizations. Vol. 1. No. 2. P. 129-54.

Broome A., Seabrooke L. (2015) Shaping Policy Curves: Cognitive Authority in Transnational Capacity Building // Public Administration. Vol. 93. No. 4. P. 956-72.

Buckley N., Belton C. (2008) Medvedev Blames US for Financial Crisis // Financial Times. 7 June. Режим доступа: https://www.ft.com/content/a5e38aaa-34bf-11dd-a47c-0000779fd2ac (дата обращения: 11.02.2019).

Büthe T., Mattli W. (2011) The New Global Rulers: The Privatization of Regulation in the World Economy. Princeton: Princeton University Press.

Clapp J., Murphy S. (2013) The G20 and Food Security: A Mismatch in Global Governance? // Global Policy. Vol. 4. No. 2. P. 129-38.

Clark G., Dixon A., Monk A. (2013) Sovereign Wealth Funds: Legitimacy, Governance, and Global Power. Princeton: Princeton University Press.

Cooper A.F. (2008) Executive but Expansive: The L20 as a Project of "New" Multilateralism and "New" Regionalism. Regionalisation and Global Governance: The Taming of Globalisation? / A.F. Cooper, C.W. Hughes, P. de Lombaerde (eds). Abingdon: Routledge.

Cooper A.F. (2010) The G20 As an Improvised Crisis Committee and/or a Contested "Steering Committee" for the World // International Affairs. Vol. 86. No. 3. P. 741-57.

Cooper A.F. (2012) The G20 as the Global Focus Group: Beyond the Crisis Committee/Steering Committee Framework. Centre for International Governance Innovation (CIGI). Режим доступа: https://www.cigionline.org/articles/g20-global-focus-group-beyond-crisis-committeesteering-committee-framework (дата обращения: 11.02.2019).

Cooper A.F., Cornut J. (2019) The Changing Practices of Frontline Diplomacy: New Directions for Inquiry // Review of International Studies. Vol. 45. No. 2. P. 300-319.

Cooper A.F., Thakur R. (2013) The Group of Twenty (G20). New York: Routledge.

Crump L., Downie C. (2018) The G20 Chair and the Case of the Global Economic Steering Committee // Global Society. Vol. 32. No. 1. P. 23-46.

Department of International Relations and Cooperation, Republic of South Africa (2014) Chairperson's Statement on the BRICS Foreign Ministers Meeting Held on 24 March 2014 in The Hague. Режим доступа: http:// www.dirco.gov.za/docs/2014/brics0324.html (дата обращения: 12.02.2017).

Dingwerth K., Pattberg P. (2006) Global Governance as a Perspective on World Politics // Global Governance. Vol. 12. P. 185-206.

Easterly W. (2003) IMF and World Bank Structural Adjustment Programs and Poverty. Managing Currency Crises in Emerging Markets / M.P. Dooley, J.A. Frankel (eds). Chicago: University of Chicago Press.

Eccleston R., Kellow A., Carroll P. (2015) G20 Endorsement in Post Crisis Global Governance: More Than a Toothless Talking Shop? // British Journal of Politics and International Relations. Vol. 17. P. 298-317.

Financial Stability Board (FSB), International Monetary Fund (IMF), Bank for International Settlements (BIS) (2011) Macroprudential Policy Tools and Frameworks. Progress Report to G20. Режим доступа: https://www.imf.org/external/np/g20/pdf/102711.pdf (дата обращения: 05.10.2018).

Fukuyama F. (1989) The End of History? // The National Interest. Vol. 16. P. 3-18.

Group of 20 (G20) (2011) G20 Coherent Conclusions For the Management of Capital Flows Drawing on Country Experiences as endorsed by G20 Finance Ministers and Central Bank Governors. Режим доступа: https:// www.mofa.go.jp/policy/economy/g20_summit/2011/pdfs/annex05.pdf (дата обращения: 29.03.2019). 
Gallagher K. (2011) Regaining Control? Capital Controls and the Global Financial Crisis. PERI Working Paper No 250, Political Economy Research Institute. Режим доступа: https://www.peri.umass.edu/publication/ item/download/312_ff3b761e2d45edcbb4323bf2f2a910f (дата обращения: 27.05.2019).

Gilboa E. (2008) Searching For a Theory of Public Diplomacy // The Annals of the American Academy of Political and Social Science. Vol. 616. No. 1. P. 55-77.

Guha K. (2009) IMF Refuses to Rule Out Capital Controls // Financial Times. 2 November. Режим доступа: https://www.ft.com/content/80201cce-c7ef-11de-8ba8-00144feab49a (дата обращения: 05.10.2018).

Harris Rimmer S. (2015) A Critique of Australia’s G20 Presidency and the Brisbane Summit 2014 // Global Summitry. Vol. 1. No. 1. P. 41-63.

Hopf T. (1998) The Promise of Constructivism in International Relations Theory // International Security. Vol. 23. No. 1. P. 171-200.

IEO (2014) IMF response to the financial and economic crisis. Washington, DC: Independent Evaluation Office of the IMF. Evaluation Report. Режим доступа: https://ieo.imf.org/en/our-work/evaluation-reports/ Completed/2014-1027-imf-response-to-the-financial-and-economic-crisis (дата обращения: 10.04.2019).

International Monetary Fund (IMF) (2002) An Open Letter to Joseph Stiglitz, by Kenneth Rogoff, Economic Counsellor and Director of the Research Department, IMF. IMF Views and Commentaries. 2 July. Режим доступа: https://www.imf.org/en/News/Articles/2015/09/28/04/54/vc070202 (дата обращения: 27.06.2017).

International Monetary Fund (IMF) (2003) The IMF and Recent Capital Account Crises: Indonesia, Korea, Brazil. Evaluation Report. Режим доступа: https://www.imf.org/external/np/ieo/2003/cac/pdf/all.pdf (дата обращения: 27.06.2017).

International Monetary Fund (IMF) (2009) IMF Completes First Review Under Stand-By Arrangement with Iceland, Extends Arrangement, and Approves US\$167.5 Million Disbursement. Press Release No. 09/375. 28 October. Режим доступа: http://www.imf.org/external/np/sec/pr/2009/pr09375.htm (дата обращения: 05.10.2018).

International Monetary Fund (IMF) (2015) World Economic Outlook database. Режим доступа: http://www. imf.org/external/pubs/ft/weo/2015/01/weodata/download.aspx (дата обращения: 05.10.2018).

Karlsrud J. (2016) Norm Change in International Relations: Linked Ecologies in UN Peacekeeping Operations. New York: Routledge.

Keck M.E., Sikkink K. (1999) Transnational Advocacy Networks in International and Regional Politics // International Social Science Journal. Vol. 51. No. 159. P. 89-101.

Khanna P. (2012) How Multi-Stakeholder Is Global Policy? // Global Policy. Vol. 3. No. 3. P. 384-90.

Kirton J.J. (2013) G20 Governance for a Globalized World. Farnham: Ashgate Publishing.

Kirton J.J. (2016) China’s G20 Leadership. New York: Routledge.

Kotzian P., Kohler-Koch B. (2015) Holding International Governance to Account: Do Civil Society Organizations Have a Chance to Exert Accountability? // Journal of International Organizations Studies. Vol. 6. No. 2. P. 5-26.

Krauthammer C. (1990) The Unipolar Moment // Foreign Affairs. Vol. 70. No. 1. P. 23-33.

Larionova M. (2012) From the Mexican to the Russian G20 Presidency. Global Perspective: G20 Update. Higher School of Economics. Режим доступа: https://publications.hse.ru/mirror/pubs/share/folder/jax65qrt1p/direct/63020446 (дата обращения: 05.10.2018).

Lenz H. (2018) Achieving Effective International Cooperation: How Institutional Formalization Shapes Intergovernmental Negotiations // World Affairs. Vol. 181. No. 2. P. 161-80.

Luckhurst J. (2012) The G20 and Ad Hoc Embedded Liberalism: Economic Governance Amid Crisis and Dissensus // Politics \& Policy. Vol. 40. No. 5. P. 740-82.

Luckhurst J. (2016a) G20 Since the Global Crisis. New York: Palgrave Macmillan.

Luckhurst J. (2016b) The G20's Growing Political and Economic Challenges. Global Summitry. Vol. 2. No. 2. P. $161-79$. 
Luckhurst J. (2017) The Shifting Global Economic Architecture: Decentralizing Authority in Contemporary Global Governance. New York: Palgrave Macmillan.

Narlikar A. (2017) Can the G20 Save Globalisation? GIGA Focus Global No 1, German Institute of Global and Area Studies. Режим доступа: https://nbn-resolving.org/urn:nbn:de:0168-ssoar-51669-5 (дата обращения: 27.05.2019).

Nye J.S. (2004) The Decline of America's Soft Power // Foreign Affairs. Vol. 83. Режим доступа: http:// heinonline.org/HOL/LandingPage?handle=hein.journals/fora83\&div=43\&id=\&page (дата обращения: 27.06.2017).

Organisation for Economic Co-operation and Development (OECD) (2013) Action Plan on Base Erosion and Profit Shifting. Paris: OECD. Режим доступа: https://www.oecd.org/ctp/BEPSActionPlan.pdf (дата обращения: 27.06.2017).

Organisation for Economic Co-operation and Development (OECD) (2018) Bridging the Digital Gender Divide: Include, Upskill, Innovate. Paris: OECD. Режим доступа: http://www.oecd.org/internet/bridging-thedigital-gender-divide.pdf (дата обращения: 10.04.2019).

Partlow J. (2008) Brazil's Lula Urges "Global Solutions.” Washington Post. 27 June. Режим доступа: http:// www.washingtonpost.com/wp-dyn/content/article/2008/11/08/AR2008110801329.html (дата обращения: 27.06.2017).

Paulson H. (2015) Dealing With China: An Insider Unmasks the New Economic Superpower. New York: Hachette Book Group.

Price R. (2003) Transnational Civil Society and Advocacy in World Politics // World Politics. Vol. 55. P. 579_ 606.

Rajan R.G. (2005) Has Financial Development Made the World Riskier? NBER Working Paper No 11728, National Bureau of Economic Research. Режим доступа: http://www.nber.org/papers/w11728 (дата обращения: 17.02.2017).

Ravenhill J. (2002) A Three Bloc World? The New East Asian Regionalism // International Relations of the Asia-Pacific. Vol. 2. No. 2. P. 167-95.

Reus-Smit C. (2007) International Crises of Legitimacy // International Politics. Vol. 44. No. 2-3. P. 157-74.

Rodrik D. (2006) Goodbye Washington Consensus, Hello Washington Confusion? // Journal of Economic Literature. Vol. 44. No. 4. P. 973-87.

Rodrik D. (2012) The Globalization Paradox: Why Global Markets, States, and Democracy Can't Coexist. Oxford: Oxford University Press.

Rogoff K. (2003) The IMF Strikes Back. IMF Views and Commentaries. 10 February. Режим доступа: https://www.imf.org/en/News/Articles/2015/09/28/04/54/vc021003 (дата обращения: 27.06.2017).

Rosenau J.N. (1992) Governance, Order, and Change in World Politics. Governance Without Government: Order and Change in World Politics / J.N. Rosenau, O.-E. Czempiel (eds). Cambridge: Cambridge University Press. P. 1-29.

Rosenau J.N. (1995) Governance in the Twenty-First Century // Global Governance. Vol. 1. P. 13-43.

Rudd K. (2009) The Global Financial Crisis // Australian Politics, Society \& Culture: The Monthly. February. Р. 20-9. Режим доступа: https://www.themonthly.com.au/issue/2009/february/1319602475/kevin-rudd/ global-financial-crisis (дата обращения: 19.11.2016).

Ruggie J.G. (1982) International Regimes, Transactions, and Change: Embedded Liberalism in the Postwar Economic Order // International Organization. Vol. 36. No. 2. P. 379-415.

Schirm S.A. (2013) Global Politics Are Domestic Politics: A Societal Approach to Divergence in the G20 // Review of International Studies. Vol. 39. No. 3. P. 685-706.

Scholte J.A. (2004) Civil Society and Democratically Accountable Global Governance // Government and Opposition. Vol. 39. No. 2. P. 211-33.

Seabrooke L. (2014) Epistemic Arbitrage: Transnational Professional Knowledge in Action // Journal of Professions and Organization. Vol. 1. No. 1. P. 49-64. 
Singh A., Belaisch A., Collyns C., De Masi P., Krieger R., Meredith G., Rennhack R. (2005) Stabilization and Reform in Latin America: A Macroeconomic Perspective on the Experience Since the Early 1990s. IMF Occasional Paper 238, International Monetary Fund. Режим доступа: http://www.imf.org/external/pubs/ft/ op/238/ (дата обращения: 27.06.2017).

Slaughter S. (2013) The Prospects of Deliberative Global Governance in the G20: Legitimacy, Accountability, and Public Contestation // Review of International Studies. Vol. 39. No. 1. P. 71-90.

Slaughter S. (2015) Building G20 Outreach: The Role of Transnational Policy Networks in Sustaining Effective and Legitimate Summitry // Global Summitry. Vol. 1. No. 2. P. 171-86.

Slaughter S. (2019) Interpreting Civil Society Engagement With the G20: The Qualified Inclusion of the 2014 Civil 20 Process // Globalizations. Vol. 16. No. 1. P. 36-49.

Smythe E. (2000) State Authority and Investment Security: Non-State Actors and the Negotiation of the Multilateral Agreement on Investment at the OECD. Non-State Actors and Authority in the Global System / R.A. Higgott, G.R.D. Underhill, A. Bieler (eds). New York: Routledge. P. 74-90.

Sohn I. (2005) Asian Financial Cooperation: The Problem of Legitimacy in Global Financial Governance // Global Governance. Vol. 11. No. 4. P. 487-504.

Sørensen E., Torfing J. (2007) Introduction: Governance Network Research: Toward a Second Generation // Theories of Democratic Network Governance / E. Sørensen, J. Torfing (eds). Basingstoke and New York: Palgrave Macmillan. P. 1-24.

Stiglitz J.E. (2001) Failure of the Fund. Rethinking the IMF Response // Harvard International Review. Vol. 23. No. 2. P. $14-8$.

Stiglitz J.E. (2002) Participation and Development: Perspectives From the Comprehensive Development Paradigm // Review of Development Economics. Vol. 6. No. 2. P. 163-82.

Stiglitz J.E. (2003) Globalization and the Logic of International Collective Action: Re-Examining the Bretton Woods Institutions. Governing Globalization: Issues and Institutions / D. Nayyar (ed.). Oxford: Oxford University Press. P. 238-53.

Stiglitz J.E. (2004) Capital-Market Liberalization, Globalization, and the IMF // Oxford Review of Economic Policy. Vol. 20. No. 1. P. 57-71.

Stone D. (2015) The Group of 20 Transnational Policy Community: Governance Networks, Policy Analysis and Think Tanks // International Review of Administrative Sciences. Vol. 81. No. 4. P. 793-811.

Strauss-Kahn D. (2009) Beyond the Crisis: Sustainable Growth and a Stable International Monetary System. Speech by Dominique Strauss- Kahn, Managing Director of the International Monetary Fund, at the Sixth Annual Bundesbank Lecture. September 4. Режим доступа: https://www.imf.org/external/np/speeches/2009/090409.htm (дата обращения: 30.03.2019).

Stubbs R. (2002) ASEAN Plus Three: Emerging East Asian Regionalism? // Asian Survey. Vol. 42. No. 3. P. $440-55$.

Subacchi P. (2015) Is the G-20 Still the World's Crisis Committee? // Foreign Policy. 25 November. Режим доступа: https://www.yahoo.com/news/g20-still-world-crisis-committee-203322118.html (дата обращения: 30.03.2019).

Subacchi P., Pickford S. (2011) Legitimacy vs Effectiveness for the G20: A Dynamic Approach to Global Economic Governance. Chatham House Briefing Paper. October. Режим доступа: https://www.chathamhouse. org/sites/files/chathamhouse/1011bp_subacchi_pickford.pdf (дата обращения: 27.06.2017).

United Nations (UN) (2008) Transcript of Press Conference by Secretary-General Ban Ki-Moon at United Nations Headquarters. 11 November. Press Release. Режим доступа: https://www.un.org/press/en/2008/ sgsm11916.doc.htm (дата обращения: 19.09.2015).

Utzig S. (2010) The Financial Crisis and the Regulation of Credit Rating Agencies: A European Banking Perspective. ADBI Working Paper Series No 188, Asian Development Bank Institute. Режим доступа: https:// papers.ssrn.com/sol3/papers.cfm?abstract_id=1592834\#\# (дата обращения: 11.04.2019).

Women 20 (W20) (2019) W20 Japan 2019 Communiqué. Tokyo. March 23. Режим доступа: https://w20japan. org/en/pdf/w20_communique_en.pdf (дата обращения: 11.04.2019). 
Wade R. (2012) The G192 Report // Le Monde Diplomatique, August. Режим доступа: http://mondediplo. com/2012/08/09un (дата обращения: 11.04.2019).

Watt N. (2009) "Blue-Eyed Bankers" to Blame for Crash, Lula Tells Brown // The Guardian. 26 March. Режим доступа: https://www.theguardian.com/world/2009/mar/26/lula-attacks-white-bankers-crash (дата обращения: 19.09.2015).

Widmaier W., Blyth M., Seabrooke L. (2007) Exogenous Shocks or Endogenous Constructions? The Meanings of Wars and Crises // International Studies Quarterly. Vol. 51. No. 4. P. 747-59.

Williamson J. (1990) What Washington Means by Policy Reform. Latin American Readjustment: How Much Has Happened / J. Williamson (ed.). Washington DC: Institute for International Economics. P. 7-20.

The World Bank (n. d.) World Bank database. Режим доступа: http://data.worldbank.org/indicator/NY.GDP. MKTP.CD?locations=US-1W (дата обращения: 26.06.2017)

World Bank (2005) Economic Growth in the 1990s: Learning From a Decade of Reform. Режим доступа: https://openknowledge.worldbank.org/handle/10986/7370 (дата обращения: 05.10.2018).

Wurf H., Sainsbury T. (2016) Making the Most of the G20. Lowy Institute Analyses. 29 July. Режим доступа: https://www.lowyinstitute.org/publications/making-most-g20 (дата обращения: 11.02.2019).

World Economic Forum (WEF) (2017) President Xi’s Speech to Davos in Full. World Economic Forum. Davos. 17 January. Режим доступа: https://www.weforum.org/agenda/2017/01/full-text-of-xi-jinping-keynoteat-the-world-economic-forum (дата обращения: 11.02.2019).

Ye Y. (2014) A Reflection on the G20: From Strategic to Pragmatic // G20 Monitor No. 15 / G20 Studies Centre, Lowy Institute for International Policy. C. 27-9.

Zürn M. (2018) A Theory of Global Governance: Authority, Legitimacy, and Contestation. Oxford University Press. 